\title{
ANALYSIS OF GROUND-WATER FLOWPATHS NEAR WATER- SUPPLY WELLS, PICATINNY ARSENAL, NEW JERSEY
}

By Donald E. Rice and Lois M. Voronin

U.S. GEOLOGICAL SURVEY

Water-Resources Investigations Report 96-4228

Prepared in cooperation with the

U.S. ARMY ARMAMENT RESEARCH DEVELOPMENT AND

ENGINEERING CENTER

West Trenton, New Jersey 


\section{U.S. DEPARTMENT OF THE INTERIOR \\ BRUCE BABBIT, secretary}

U.S. GEOLOGICAL SURVEY

Gordon P. Eaton, Director

For additional information write to:

\section{District Chief}

U.S Geological Survey

Mountain View Office Park

810 Bear Tavern Road, Suite 206

West Trenton, NJ 08628
Copies of this report can be purchased from:

U.S. Geological Survey

Branch of Information Services

Box 25286

Denver, CO 80225-0286 


\section{CONTENTS}

Abstract

Introduction

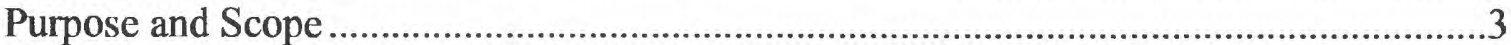

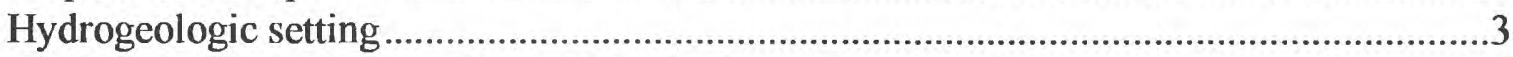

Well-construction information and numbering systems .....................................................

Ground-water-flow model of Picatinny Valley ………..........................................................

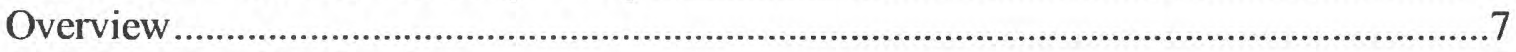

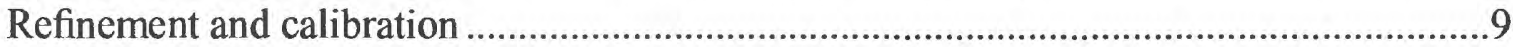

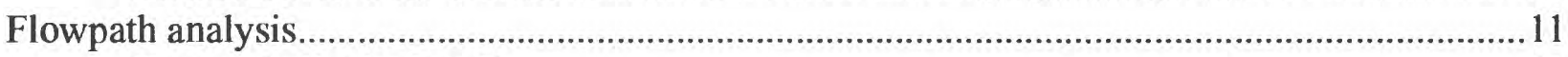

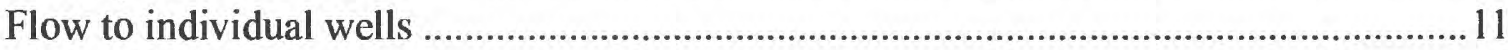

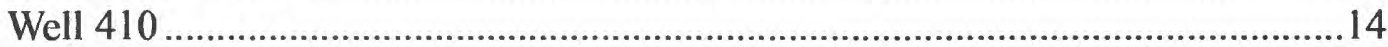

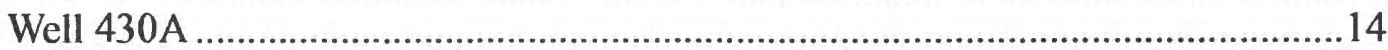

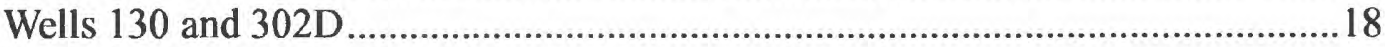

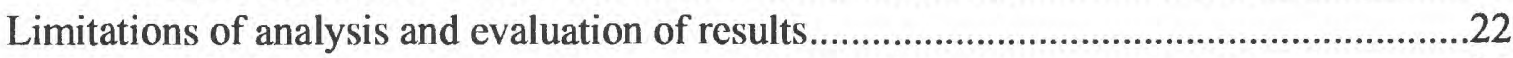

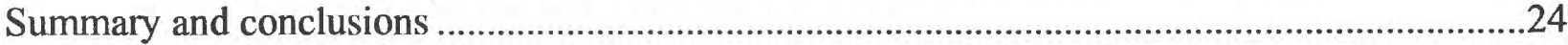

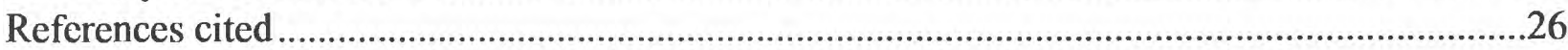

\section{ILLUSTRATIONS}

Figure 1. Map showing location of study area, water-supply wells, and hydrogeologic sections A-A' and B-B', Picatinny Arsenal, New Jersey ..........................................

2. Schematic diagram of section A-A' (down the valley) showing model layers, Picatinny Arsenal, New Jersey .........................................................................

3. Schematic diagram of section B-B' (across the valley) showing model layers, Picatinny Arsenal, New Jersey

4. Schematic diagram showing the finite-difference grid and location of model boundaries in the unconfined aquifer used in the valley-wide ground-waterflow model, PicatinnyArsenal, New Jersey, and vicinity.

5-6. Maps showing:

5. Locations of springs and spring-discharge measurements in the vicinity of wells 410 and 430A, Picatinny Arsenal, New Jersey

6. Simulated average unstressed potentiometric surface and water levels measured in January 1993 in the vicinity of water-supply wells at Picatinny Arsenal, New Jersey, in

(a) model layer $\mathrm{A} 3$ and

(b) model layer A5

7. Graphs showing monthly withdrawals from water-supply wells 130,410 , and

430A, Picatinny Arsenal, New Jersey,1959-1993

8-13. Maps showing:

8. Contributing area to water-supply well 410 at Picatinny Arsenal, New Jersey, showing ranges of ground-water travel time from the contributing area to the well 


\section{ILLUSTRATIONS--Continued}

Page

Figure 9. Contributing area to water-supply well $430 \mathrm{~A}$ at Picatinny Arsenal, New Jersey, showing ranges of ground-water travel time from the contributing area to the well

10. Contributing area to water supply wells 410 and $430 \mathrm{~A}$ at Picatinny Arsenal, New Jersey, combined

11. Contributing area to water-supply well 130 at Picatinny Arsenal, New Jersey, showing ranges of ground-water travel time from the contributing area to the well

12. Contributing area to water-supply well 302D at Picatinny Arsenal, New Jersey, showing ranges of ground-water travel time from the contributing area to the well

13. Areas of plume of trichloroethylene-contaminated ground water originating at building 24 at Picatinny Arsenal, New Jersey, predicted to contribute ground water to well 130 from permeable layer (a)A1, (b)A2, and (c)A3

\section{TABLES}

Table 1. Well-construction and numbering information for four water-supply wells at Picatinny Arsenal, New Jersey 


\section{CONVERSION FACTORS, VERTICAL DATUM, AND ABBREVIATED WATER-QUALITY UNITS}

Multiply

foot (ft)

mile ( $\mathrm{mi}$ )
By

Length

$$
\begin{aligned}
& 0.3048 \\
& 1.609
\end{aligned}
$$

square foot $\left(\mathrm{ft}^{2}\right)$ gallon (gal)

gallon (gal)

million gallons (Mgal)

$\begin{array}{cl}3.785 & \text { liter } \\ 0.003785 & \text { cubic meter } \\ 3,785 & \text { cubic meter }\end{array}$

Hydraulic conductivity

foot per day $(\mathrm{ft} / \mathrm{d})$

0.3048

\section{Area}

929.0

meter

kilometer

square centimeter

$$
\begin{array}{cl}
\text { Volume } & \\
3.785 & \text { liter } \\
0.003785 & \text { cubic meter } \\
3,785 & \text { cubic meter }
\end{array}
$$

Sea level: In this report "sea level" refers to the National Geodetic Vertical Datum of 1929-- a geodetic datum derived from a general adjustment of the first-order level nets of the United States and Canada, formerly called Sea Level Datum of 1929.

Water-quality abbreviations:

VOC - volatile organic compound 


\title{
ANALYSIS OF GROUND-WATER FLOWPATHS NEAR WATER-SUPPLY WELLS, PICATINNY ARSENAL, NEW JERSEY
}

\author{
By Donald E. Rice and Lois M. Voronin
}

\begin{abstract}
Ground-water flow to active and proposed water-supply wells screened in glacial sediments or open to bedrock at Picatinny Arsenal (in Picatinny Valley), New Jersey, under steadystate pumping conditions was simulated with a three-dimensional finite-difference valley-wide flow model. The model was adjusted to account for discharge from springs at the base of the southeastern valley wall that infiltrates to the subsurface and recharges the unconfined aquifer. The model was calibrated to measurements of discharge in Green Pond Brook and to measurements of ground-water levels in January 1993. A particle-tracking flowpath analysis of simulation results for selected pumping alternatives was conducted to determine the contributing areas of two active and two proposed water-supply wells, and the travel times from the contributing areas to the wells.

Contributing areas of active water-supply wells 410 and $430 \mathrm{~A}$ include parts of Picatinny Lake and areas near the southeastern valley wall. Several documented and potential sources of ground-water contamination are present in the unsaturated zone above areas at the water table from which predicted travel times to the wells are 10 years or less. Contributing areas of alternate water-supply wells 130 and 302D are located mainly between Bear Swamp Brook and the northwestern valley wall, and include areas that are near documented and potential sources of groundwater contamination in the vicinity of building 24 . Predicted travel time from the building 24 area to well $302 \mathrm{D}$ is generally longer than that from the building 24 area to well 130 . A particletracking analysis of ground-water flow from a trichloroethylene plume originating near building 24 indicated that, under simulated pumping conditions, water discharging from well 302D would not include any water from the plume; however, water from the plume would reach well 130.
\end{abstract}

\section{INTRODUCTION}

Ground water is the sole source of potable water at Picatinny Arsenal in northern New Jersey (fig. 1). The continued supply of potable water at the arsenal depends on the availability of ground water whose quality meets New Jersey drinking-water standards. Water-supply wells 410 and $430 \mathrm{~A}$ provide much of the potable water for Picatinny Arsenal. Wells 302D and 130 are currently inactive but have been proposed for use as alternate water-supply wells, which are needed so that active supply wells can be shut down for required maintenance and as emergency sources of water if the quality of water pumped from the active wells ceases to meet New Jersey drinking-water standards. These four wells are located in Picatinny Valley southwest of Picatinny Lake (fig. 1). Wells 410 and $430 \mathrm{~A}$ are nearest the lake, in an abandoned explosives-manufacturing area. Wells 130 and 302D are located across Green Pond Brook from and southwest of wells 410 and $430 \mathrm{~A}$ in an area of the arsenal where weapons research is still conducted. 
EXPLANATION

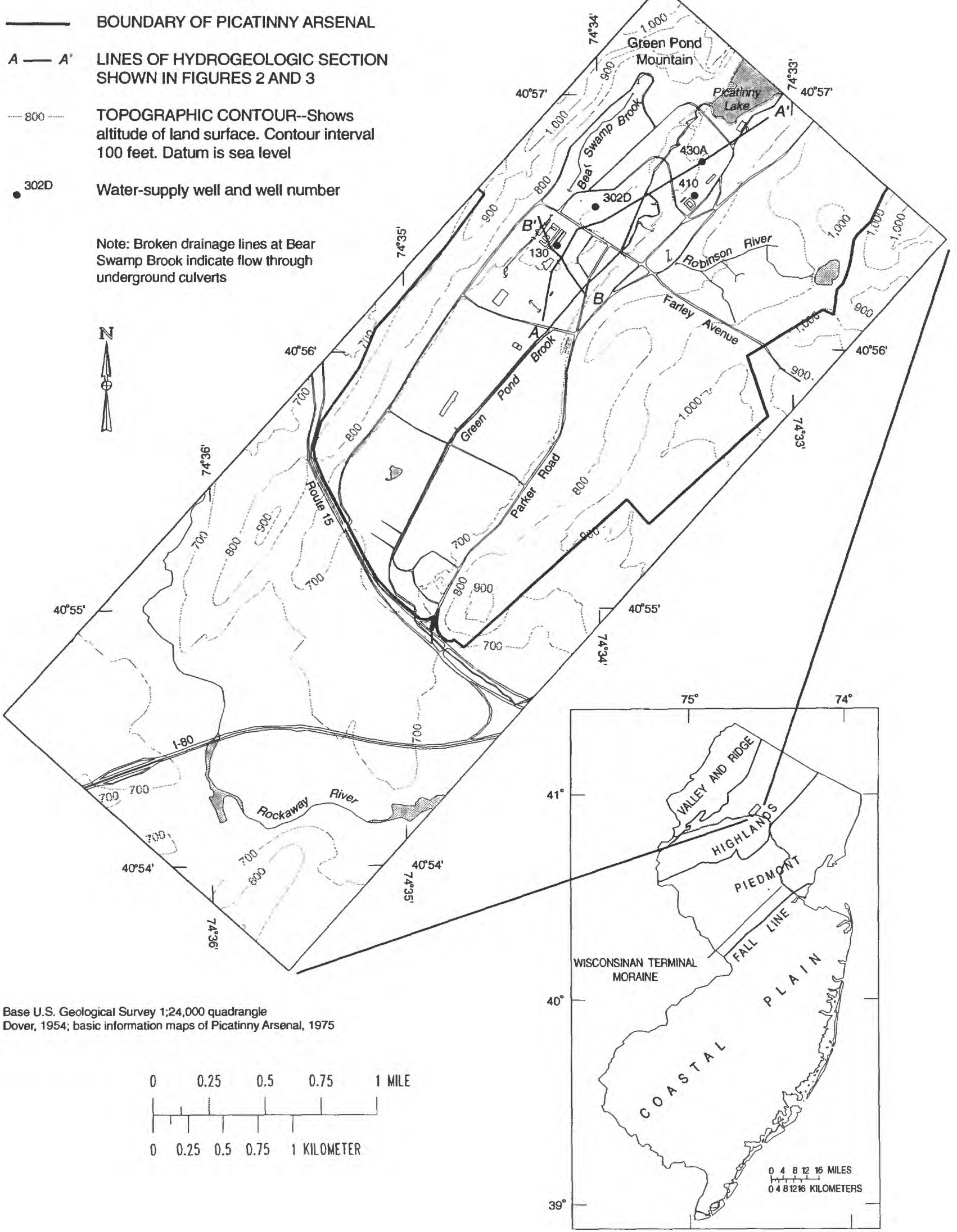

Figure 1. Location of study area, water-supply wells, and hydrogeologic sections $A-A^{\prime}$ and $B-B^{\prime}$, Picatinny Arsenal, New Jersey. 
All four wells are located near documented and potential sources of ground-water contamination (Robert Rosman, U.S. Geological Survey, written commun., 1991; Carpenter Environmental Associates, Inc., 1991; Sargent and others, 1990; Benioff and others, 1991), and volatile organic compounds (VOC's) have been detected in all four wells (Sargent and others, 1986). Concentrations of VOC's detected in wells 410, 430, and 302D have varied with time, but were either below drinking-water standards or absent. Trichloroethylene (TCE) was detected in samples collected from well 130 from 1981 to 1984 at concentrations ranging from 1.8 to 260 micrograms per liter (Sargent and others, 1986). Withdrawals from well 130 were stopped in 1985. The source of the TCE in the water from well 130 is presumed to be the plume of TCEcontaminated ground water originating near building 24 (Imbrigiotta and Martin, 1991). Because the plume is dynamic, it is unknown whether it still could be a source of contaminated ground water to well 130 if the well were restored to use. As part of an effort to characterize the quality of the ground water flowing to these water-supply wells, the U.S. Geological Survey (USGS), in cooperation with the U.S. Army Armament Research Development and Engineering Center, simulated ground-water flow to each well. Particle-tracking flowpath analyses of simulation results were used to identify contributing areas and to determine ground-water travel times from the contributing areas to the water-supply wells. The contributing areas and travel times were used as qualitative indicators of the potential of these wells to intercept contaminated ground water under pumping conditions.

\section{Purpose and Scope}

This report presents the results of an analysis of the ground-water flowpaths to watersupply wells 410, 430A, 302D, and 130 at Picatinny Arsenal, New Jersey. Results of the application of a particle-tracking program (Pollock, 1989) that used output from a three-dimensional finite-difference ground-water-flow model of the Picatinny Valley ground-water flow system (Voronin, 1991) to determine the three-dimensional flowpaths of water to the wells are presented. These results include the delineation of contributing areas to, and the travel time from the contributing areas to, each of the wells. An analysis of particle-tracking results that assesses each well's susceptibility to contamination is provided. To assess the potential for contaminated ground water to reach the wells, the contributing areas, flowpaths, and travel time along the flowpaths to the wells are examined in relation to documented and potential contaminant source areas near the contributing areas and flowpaths.

\section{Hydrogeologic Setting}

Picatinny Arsenal is located in the central part of the New Jersey Highlands (fig. 1), a northeast-southwest-trending system of rocks that form a sequence of broad, level highlands separated by long, narrow valleys (Wolfe, 1977). Glaciers advanced across the study area at least twice during the Quaternary Period. As a result, the bedrock surface is covered by a mantle of unconsolidated glacial deposits, predominantly till in the upland areas and stratified drift in Picatinny Valley. Glacial sediments in Picatinny Valley range in thickness from about $90 \mathrm{ft}$ near Picatinny Lake to $185 \mathrm{ft}$ at the southern boundary of Picatinny Arsenal.

The Picatinny Valley ground-water-flow system consists of a sequence of glacial aquifers and intervening confining units that overlie a carbonate-bedrock aquifer. Natural controls on the ground-water-flow system are the permeability of the bedrock and glacial sediments, the distribu- 
tion of ground-water recharge, and the location of streams. Recharge from precipitation enters the system at the water table. Additional recharge enters the unconfined aquifer at the valley wall. The low permeability and steep slopes of Green Pond Mountain and the unnamed mountain across Picatinny Valley from Green Pond Mountain restrict the infiltration of precipitation. Most precipitation that falls on the mountains recharges the unconfined aquifer by flowing downhill to their bases and then infiltrating into the highly permeable glacial sediments along the valley wall. Recharge that enters the Picatinny Valley ground-water-flow. system flows horizontally within and vertically between the glacial and bedrock aquifers until it discharges either to the streams within the valley (Green Pond Brook, Bear Swamp Brook, and the Rockaway River) or to pumped wells.

The cross-sectional relations of the glacial and bedrock aquifers down the axis of Picatinny Valley and across Picatinny Valley are shown in figures 2 and 3, respectively. Figure 2 illustrates that wells 130,410, and 430A are screened in a confined glacial aquifer, whereas well 302D is open to the carbonate-bedrock aquifer. Not all of the aquifers and confining units are present beneath the valley throughout its extent. The presence of the glacial aquifers is controlled by their depositional history. The geometry of the flow system is described in detail by Voronin (1991).

\section{Well-Construction Information and Numbering Systems}

Well-construction information--completion date, screened interval, and the aquifer to which the well is open--is presented in table 1 for the four water-supply wells discussed in this report. Table 1 also includes both the USGS well number and the local identification number assigned to the well by U.S. Army personnel at Picatinny Arsenal. The USGS well-numbering system has been used in New Jersey since 1978. The well number consists of a county code number and a sequence number assigned to each recorded well within the county. The county code number for Morris County, where Picatinny Arsenal is located, is 27. The U.S. Army local identification number identifies the well by the number of the building in which the well head is located. The water-supply wells discussed in this report are identified by their local identification number; the corresponding USGS well number can be obtained from table 1. All other wells mentioned in this report are identified by their USGS well number.

Table 1. Well-construction and numbering information for four water-supply wells at Picatinny Arsenal, New Jersey

[USGS, U.S. Geological Survey; G.S., glacial sediments; 00-00, month and day unknown; ft, feet; LSD, land-surface datum]

\begin{tabular}{llllcc}
\hline $\begin{array}{c}\text { USGS } \\
\text { well } \\
\text { number }\end{array}$ & $\begin{array}{c}\text { Local } \\
\text { identification } \\
\text { number }\end{array}$ & $\begin{array}{c}\text { Date } \\
\text { completed }\end{array}$ & $\begin{array}{c}\text { Aquifer } \\
\text { material }\end{array}$ & $\begin{array}{c}\text { Depth of } \\
\text { screened } \\
\text { interval } \\
\text { (ft below LSD) }\end{array}$ & $\begin{array}{c}\text { Elevation of } \\
\text { land surface (ft } \\
\text { above } \\
\text { sea level) }\end{array}$ \\
\hline \hline $27-82$ & 130 & $02-27-48$ & G.S. & $102-117$ & 701.59 \\
$27-83$ & $302 \mathrm{D}$ & $00-00-21$ & Bedrock & $110-403$ & 697.02 \\
$27-84$ & $430 \mathrm{~A}$ & $08-05-43$ & G.S. & $62-82$ & 701.41 \\
$27-86$ & 410 & $10-19-42$ & G.S. & $75-85$ & 710.98 \\
\hline
\end{tabular}


FEET

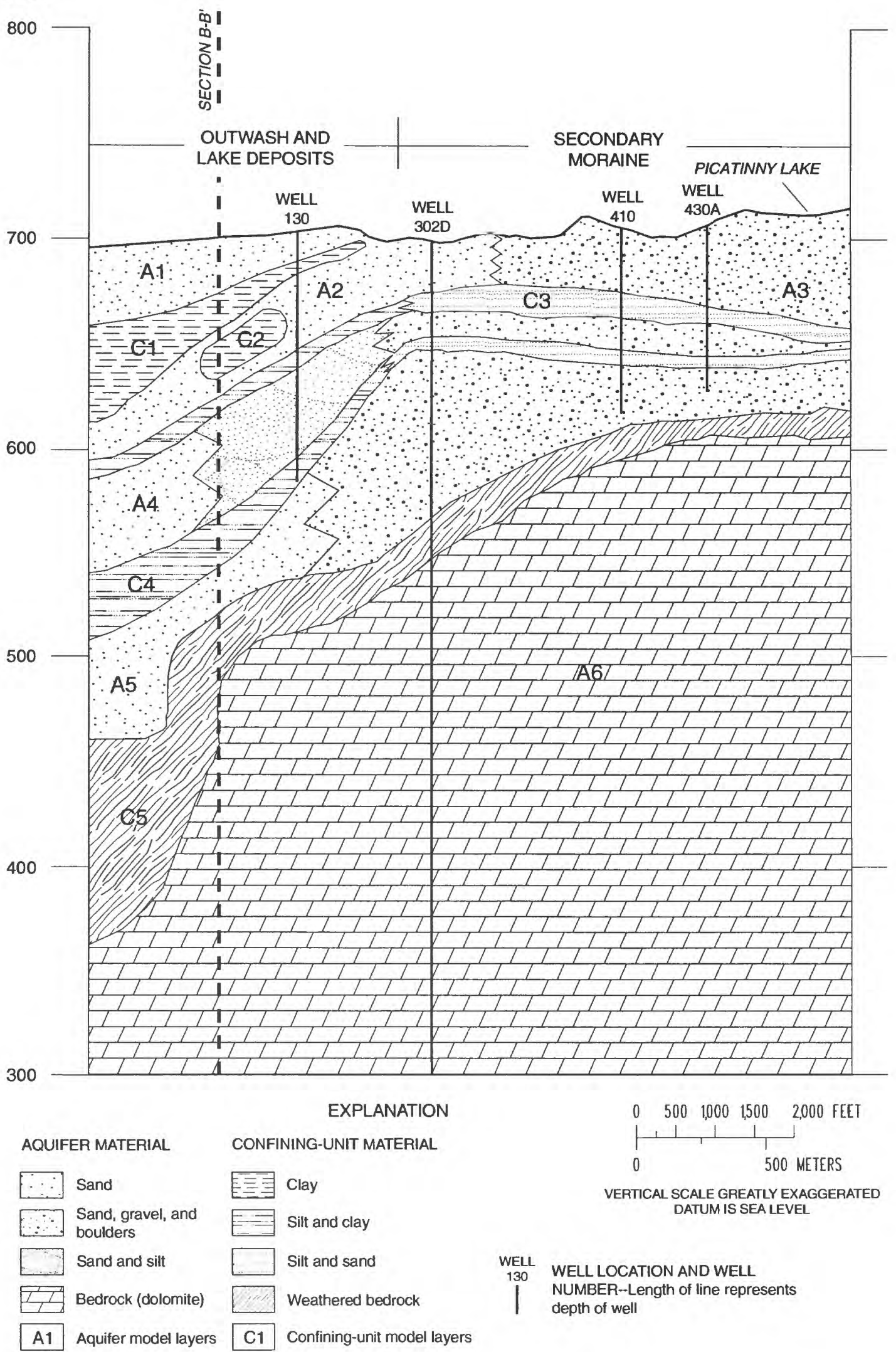

Figure 2. Section $A-A^{\prime}$ (down the valley) showing model layers, Picatinny Arsenal, New Jersey (Modified from Voronin, 1991; location of section shown in fig. 1). 
FEET

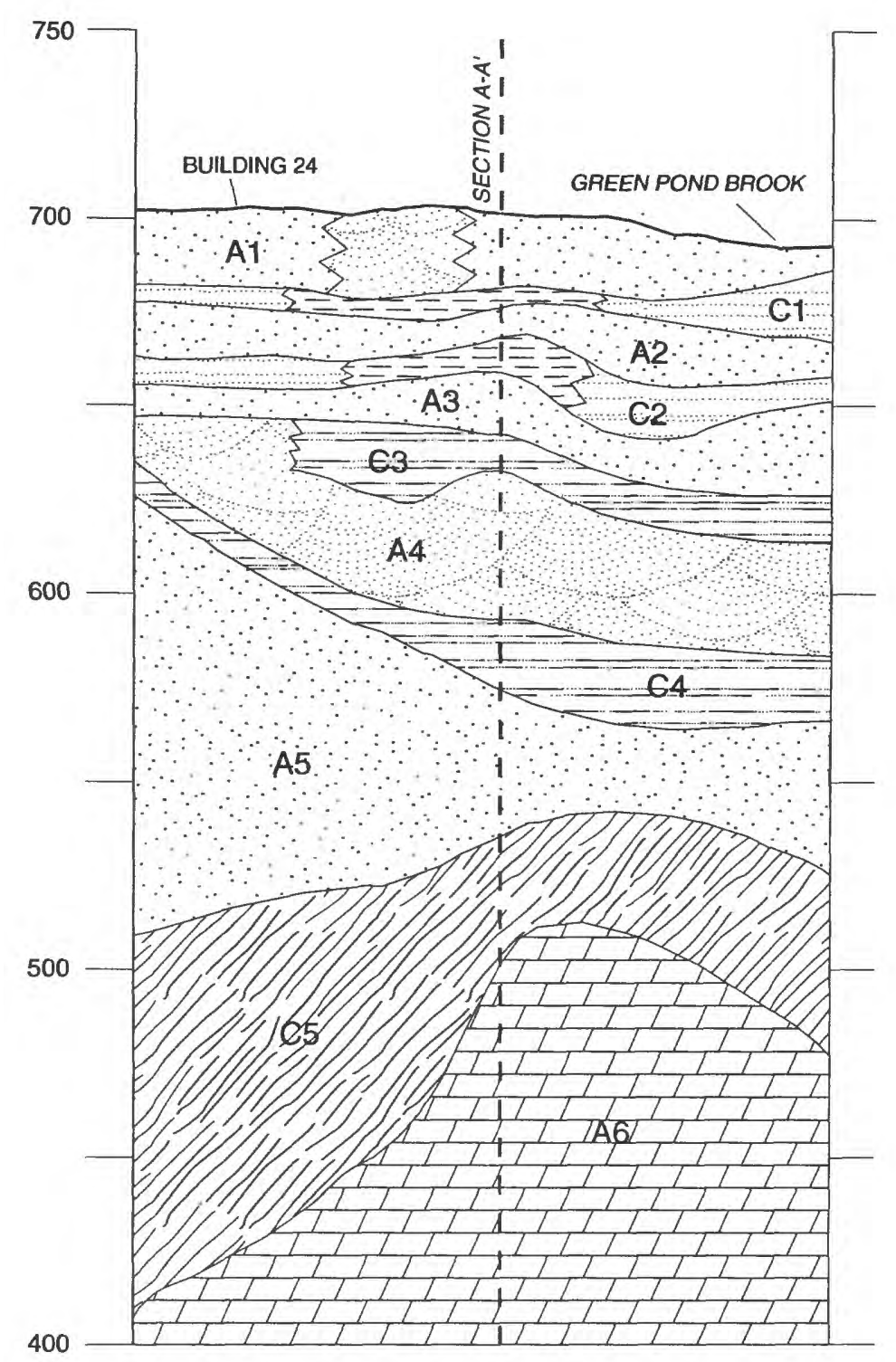

\section{EXPLANATION}

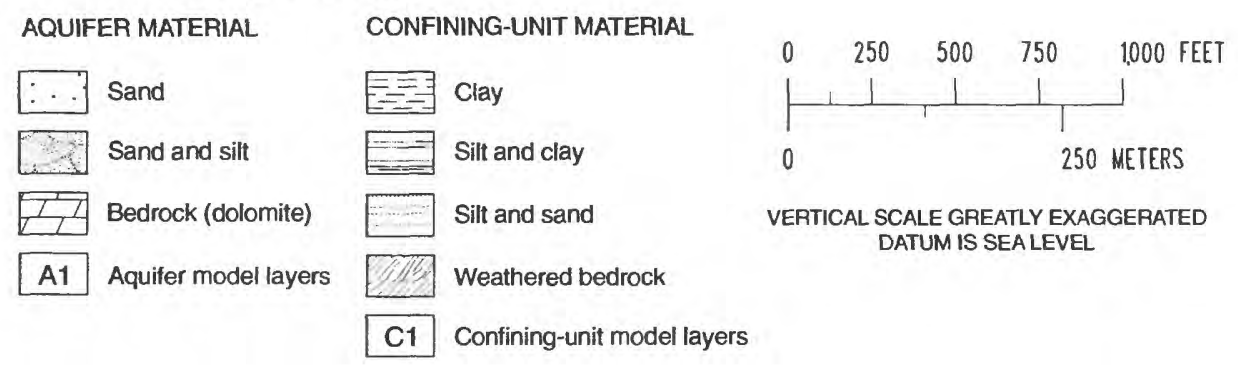

Figure 3. Section $B-B^{\prime}$ (across the valley) showing model layers, Picatinny Arsenal, New Jersey (Modified from Voronin, 1991; location of section shown in fig. 1). 


\section{GROUND-WATER-FLOW MODEL OF PICATINNY VALLEY}

A finite-difference ground-water-flow model (McDonald and Harbaugh, 1983) was used by Voronin (1991) to simulate ground-water-flow in the glacial sediments and bedrock within Picatinny Valley. This section describes the model used by Voronin (1991), which was adapted for use this study.

\section{Overview}

The model used by Voronin (1991) uses a quasi-three-dimensional approach in which flow through confining units is vertical and is represented by the vertical conductance between layers (McDonald and Harbaugh, 1983, p. 2-34). It was used in this study to simulate valley-wide ground-water flow under conditions of average recharge (for the period 1980-89) with the watersupply wells pumped after the flow system reached equilibrium. A finite-difference grid consisting of 36 rows and 95 columns was used to discretize the model layers. The model grid and its relation to Picatinny Valley are shown in figure 4 . The grid spacing is variable, ranging from 70 to $800 \mathrm{ft}$, with cell areas ranging from 5,600 to $320,000 \mathrm{ft}^{2}$.

For the purposes of simulation, Voronin (1991) divided the bedrock and glacial sediments at Picatinny Arsenal into a vertical sequence of six permeable layers and five intervening lowpermeability layers on the basis of the general hydraulic properties of the sediments. Permeable units of unconsolidated material thicker than $10 \mathrm{ft}$ and the carbonate-bedrock aquifer were identified as the probable pathways of flow and, therefore, were designated as permeable layers. Confining units, such as thick clay layers, do not appear to be present in Picatinny Valley; however, layers that contain clay and (or) silt that substantially impede the flow of ground water are present and were simulated as confining units. The six permeable layers beneath the valley are referred to in the model as A1 through A6; A6 represents the deepest permeable layer, the bedrock aquifer. The intervening low-permeability confining units are identified as $\mathrm{C} 1$ to $\mathrm{C} 5$, with confining unit C5 separating permeable layer A5 from permeable layer A6.

Model-boundary locations are shown in figure 4. The upper model boundary (the water table) includes constant heads at Picatinny Lake (the northeastern part of the model area) and the Rockaway River (the southwestern part of the model area) and areally distributed recharge (23.3 in/yr). Surface-water runoff from the mountains adjacent to Picatinny Valley was simulated as additional recharge (specified flux) along the valley wall. Green Pond Brook, Bear Swamp Brook, and drainage ditches in the southern part of the arsenal are simulated as head-dependent leakage boundaries. The lateral boundaries below the water-table layer at Picatinny Lake, at Rockaway River, and along the valley walls are no-flow boundaries. All ground-water flow from upvalley is assumed to reach the Rockaway River, either as discharge to Green Pond Brook or Bear Swamp Brook (which then flows as stream discharge to the Rockaway River) or by direct discharge to the river. The thickness of the carbonate bedrock is much greater than $300 \mathrm{ft}$; however, the bedrock aquifer in the model is $300 \mathrm{ft}$ thick because the permeability of the bedrock was assumed to decrease with depth. The lower model boundary (beneath the bedrock) is a no-flow boundary. 


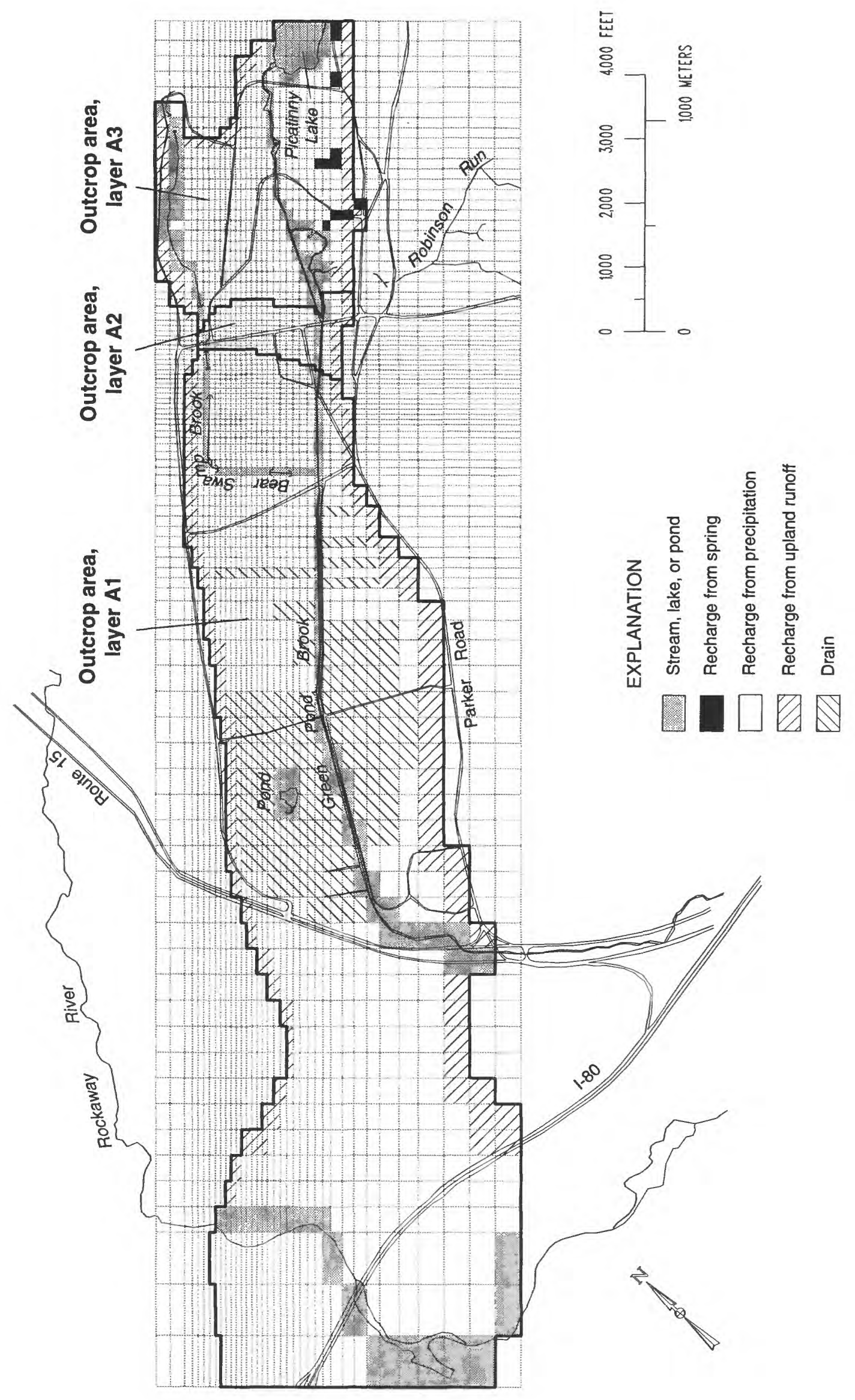

各

름

.

Dृ

过

.$\Xi$

总

$\overline{0}$

․․

4

율

으

돓

믐

总离

选

$\checkmark$ मे

窇 


\section{Refinement and Calibration}

The three-dimensional finite-difference valley-wide flow model developed by Voronin (1991) was refined to reflect recently observed hydrologic conditions. In 1992, springs were identified near the base of the southeastern valley wall. The water that discharges from the springs flows a short distance into the valley, then infiltrates to the subsurface. The discharge from these springs was measured, and the discharge values were used in the model as point sources of aquifer recharge in the areas where the water from the springs was observed to infiltrate. This refinement to the model was considered to be necessary because (1) the springs are located sufficiently close to (less than $3,000 \mathrm{ft}$ from) wells 410 and $430 \mathrm{~A}$ that the water from them could flow to the pumped wells, and (2) the additional recharge to the model from the springs improved model calibration for permeable layer A3 around Picatinny Lake. The locations of the springs, the areas where infiltration was observed, and the discharge of each spring measured in January 1993 are shown in figure 5. The combined discharge from the springs resulted in an additional input to the model of $0.2 \mathrm{Mgal} / \mathrm{d}$ of recharge. The grid location of permeable layer A3 where the recharge from the springs was input is shown in figure 4.

Recharge from runoff down the mountain slopes adjacent to Picatinny Valley was input to the water-table layers along the southeastern and northwestern boundaries of the model (fig. 4). In the original model (Voronin, 1991), this recharge was distributed along the boundaries of each permeable layer because runoff from the slopes was assumed to enter the bedrock beneath them and flow within the bedrock into each permeable layer. In the current study, this recharge was redistributed only to the water-table layers because the runoff was assumed to flow on the surface or at a shallow depth within the bedrock beneath the slopes. This assumption is believed to better represent actual recharge conditions.

Ground-water levels throughout the arsenal were measured synoptically in January 1993, and stream discharge was measured concurrently at five sites on Green Pond Brook between Picatinny Lake and Route 15, so that the model could be calibrated to a recent and more complete data set than the one used for initial model calibration. Water levels in 166 wells, screened in the six permeable layers, were measured. The measurements included water levels in two observation wells (27-1725 and 27-1726) installed by the USGS between wells 410 and 430A and Green Pond Brook, and a well (27-1732) installed by a consulting firm investigating a fuel-oil spill near building 506 (Carpenter Environmental Associates, 1991). The three wells are shown in figure 5; all of them are screened in permeable layer $\mathrm{A} 3$, and none of them had been used previously to evaluate simulation results.

The model was used to simulate average hydrologic conditions from 1982 through April 1989 with no wells pumping--that is, steady-state unstressed conditions. Water levels measured in January 1993 were about $1 \mathrm{ft}$ higher than the average water levels during the simulated period. Water levels simulated by the calibrated steady-state model, therefore, should be slightly lower than those measured in January 1993. The model was calibrated to unstressed conditions because the water-supply wells were not being pumped when the water levels were measured; therefore, the measured water levels are representative of unstressed conditions. 


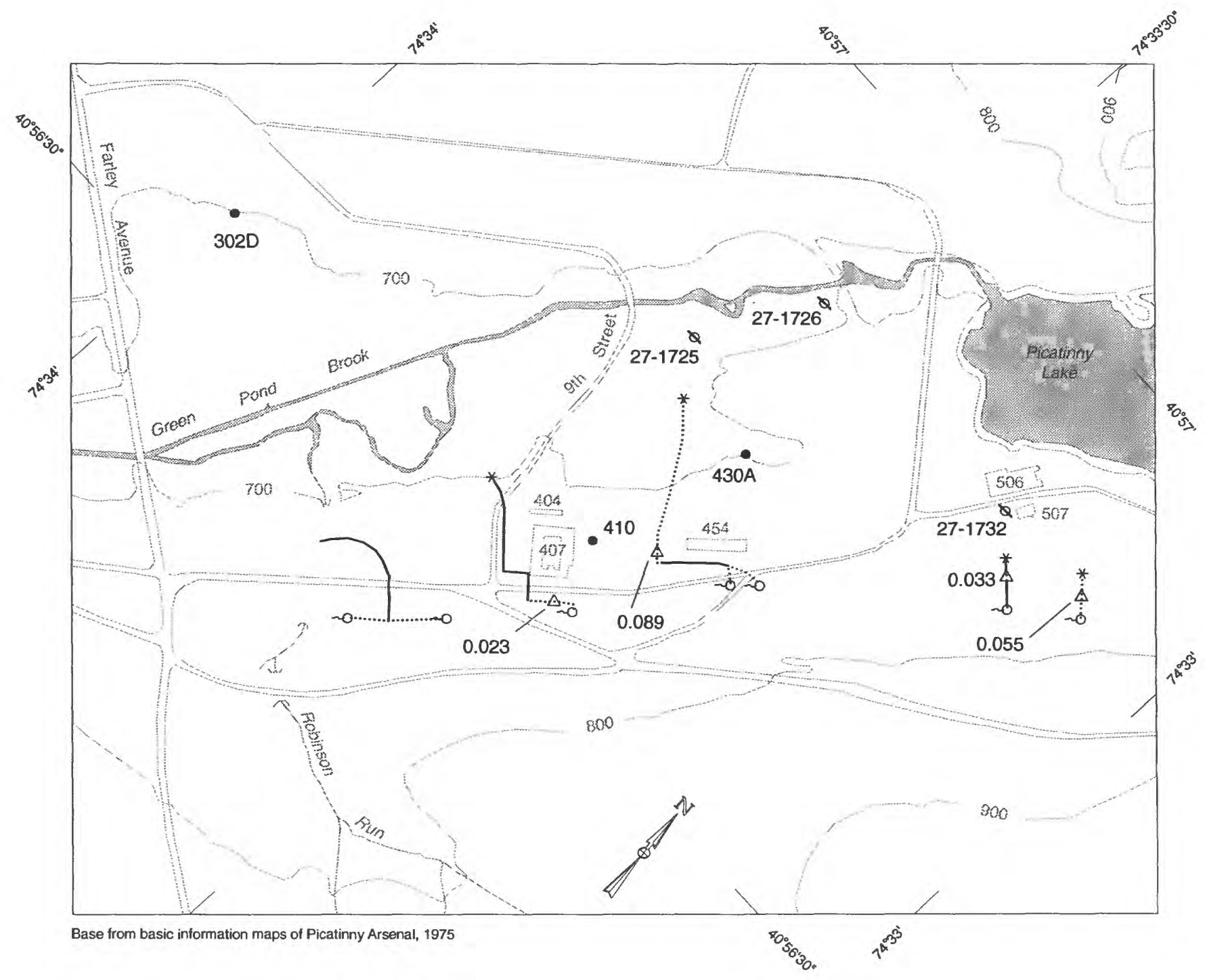

\section{EXPLANATION}

\section{$50 ?$ BUILDING WITH BUILDING NUMBER}

- 800 -..... TOPOGRAPHIC CONTOUR--Shows line of equal land-surface elevation. Interval 100 feet. Datum is sea level

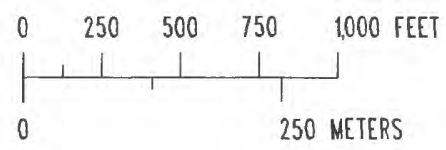

SPRING DRAINAGE CHANNEL WHERE INFILTRATION OCCURS

STORM SEWER WHERE INFILTRATION IS PREVENTED

430A - WATER-SUPPLY WELL AND LOCAL IDENTIFICATION NUMBER

27-1732 \& OBSERVATION WELL. AND U.S. GEOLOGICAL SURVEY WELL NUMBER

- SPRING

$0.033 \triangle$ SPRING-DISCHARGE-MEASUREMENT SITE--Number is discharge in million gallons per day

* OBSERVED LIMIT OF INFILTRATION OF WATER IN SPRING DRAINAGE CHANNEL

Note: Broken drainage lines at Robinson Run indicate flow through underground culverts

Figure 5. Locations of springs and spring-discharge measurements in the vicinity of wells 410 and 430A, Picatinny Arsenal, New Jersey. 
The model was calibrated by adjusting horizontal and vertical hydraulic conductivities of permeable layers and confining units and hydraulic conductivity of stream boundaries until a good match between the simulated and measured values of ground-water levels, ground-water gradients at well clusters, and stream discharge was achieved. Calibration was considered to be acceptable when the simulated water levels were similar to the measured water levels and the simulated stream discharges were similar to the measured discharges in Green Pond Brook. Potentiometric-surface contours interpreted from model-predicted heads and the water levels measured in January 1993 are shown for permeable-layers A3 and A5 in figures 6a and 6b. Calibrated horizontal hydraulic conductivities of the permeable layers ranged from 10 to $500 \mathrm{ft} / \mathrm{d}$. Calibrated vertical hydraulic conductivities of the confining units ranged from 0.01 to $0.5 \mathrm{ft} / \mathrm{d}$.

\section{FLOWPATH ANALYSIS}

Flowpaths to wells 410, 430A, 302D, and 130 were determined from the output of the calibrated valley-wide flow model. Model output was used in a particle-tracking post-processing package developed by Pollock (1989) to determine the contributing area for the flow to each well and the travel time along flowpaths from the contributing area to the well. Travel times are reported in ranges of 10 years or less, greater than 10 but less than 40 years, and 40 years or greater. These arbitrary ranges are intended to provide general estimates of ground-water travel time that can be used to the evaluate the risk that contaminants that originated within or near a well's contributing area will reach the pumped well.

The particle-tracking method calculates flowpaths and travel time from the average linear velocities computed by a steady-state, finite-difference ground-water-flow model, such as the Picatinny valley-wide flow model. The method derives an analytical expression that describes the three-dimensional velocity field within each model cell. Once the three-dimensional velocity distribution is known for each model cell, the unique path of a particle at any position in the model domain can be calculated, as can the travel time of the particle along the path. Particle paths can be determined either in the forward direction (in the direction of flow) or in the reverse direction (opposite the direction of flow). A forward-tracking procedure was used here. Particles were placed on the top surface of cells in the water-table layers and were tracked in the forward direction. The starting locations of the particles that discharged to a specified pumped watersupply well were recorded, along with the time required for those particles to travel from the starting location along the flowpath to the well. The combined starting locations of particles that discharged to a pumped well were assumed to represent that well's contributing area.

\section{Flow to Individual Wells}

The pumping alternatives selected for simulation and flowpath analysis are based on historical pumping patterns and rates, and on potential future patterns. Well 302D is an alternate water-supply well that is proposed to be used in combination with wells 410 and $430 \mathrm{~A}$; therefore, the flowpaths to wells $410,430 \mathrm{~A}$, and 302D were determined from results of a simulation in which the three wells pumped simultaneously under equilibrium conditions. The flowpaths to well 130, the other alternate water-supply well, were determined from results of a simulation in which only well 130 was pumped under equilibrium conditions; though well 130 is proposed to be pumped at the same time as wells 410 and $430 \mathrm{~A}$, the latter two wells are located sufficiently far from well 130 that their use would be unlikely to affect flowpaths to well 130 . 

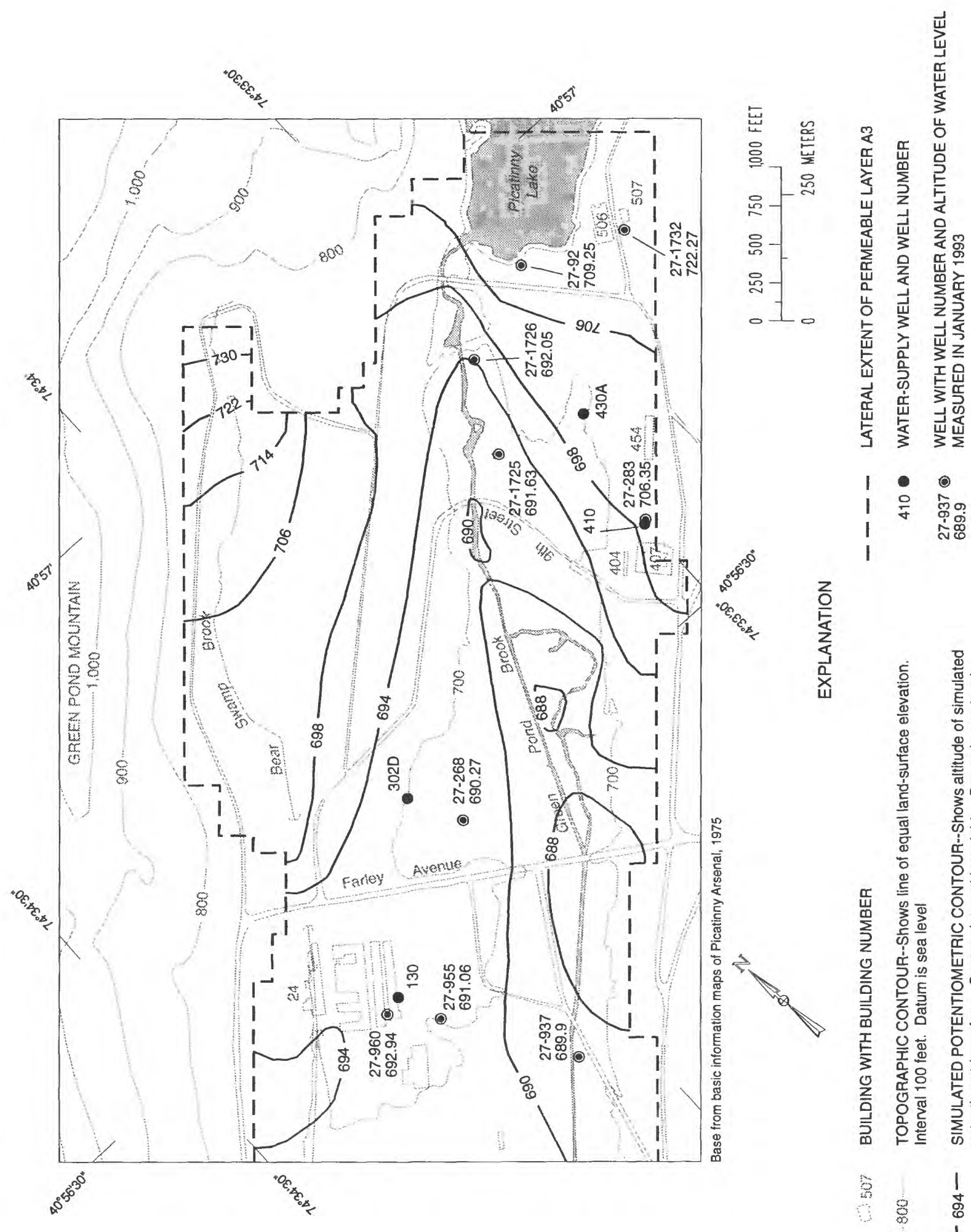

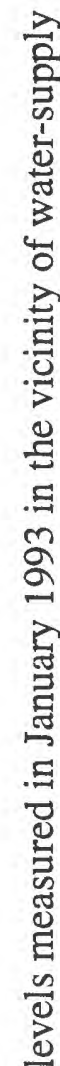

을

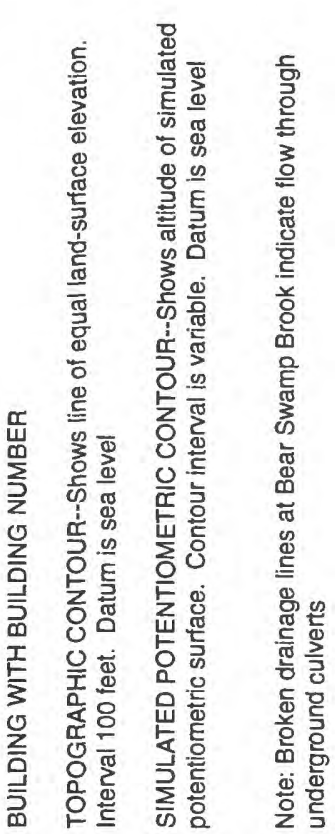

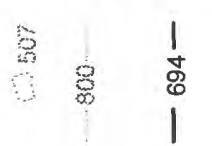



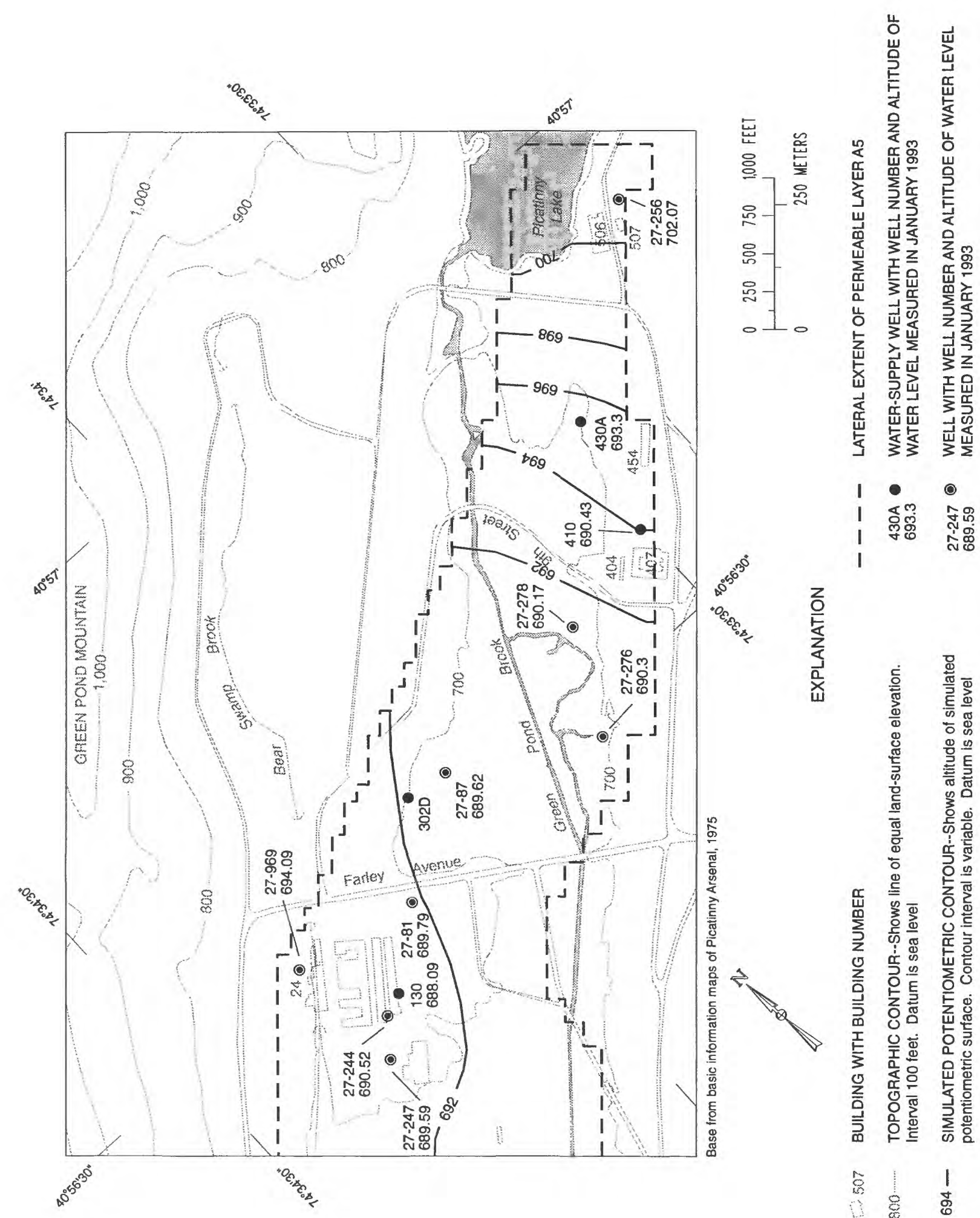

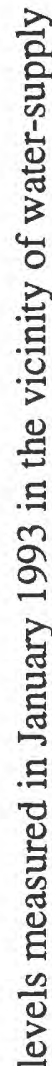

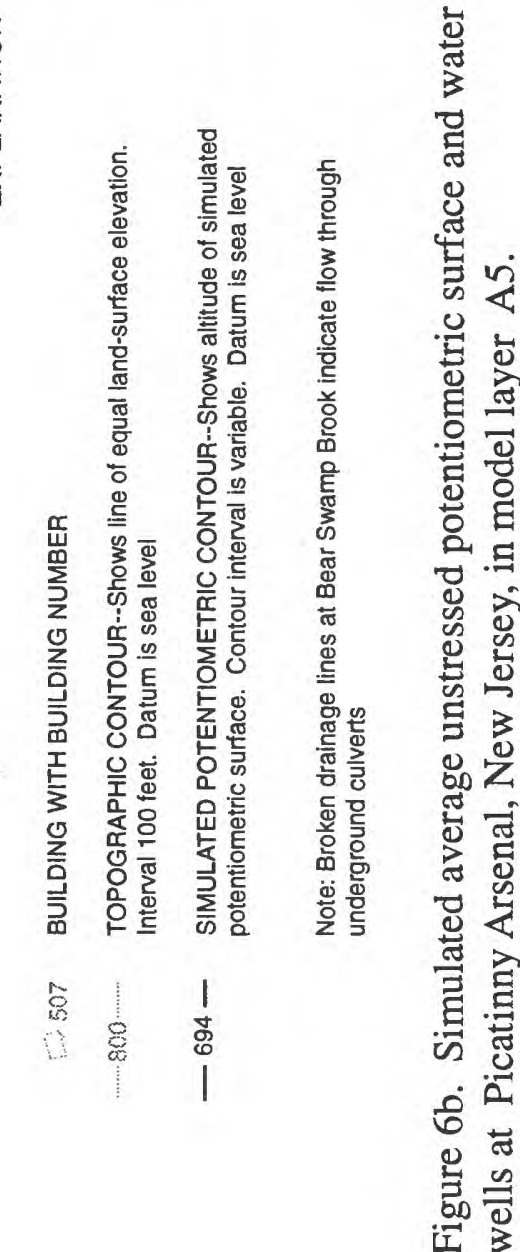


Historical pumping rates for wells 130,410 , and $430 \mathrm{~A}$ are shown in figure 7 ; no rate information is available for well 302D. The pumping rates input to the model reflect actual or potential pumping rates for each well and were obtained from arsenal personnel (Roy Oakes, Department of Public Works, oral commun., 1993). These pumping rates do not account for those times when the well is not being pumped and, therefore, are greater than the historical rates. The pumping rates for the water-supply wells input to the model were $0.432 \mathrm{Mgal} / \mathrm{d}$ for well $130,0.35 \mathrm{Mgal} / \mathrm{d}$ for well 302D, $0.4536 \mathrm{Mgal} / \mathrm{d}$ for well 410 , and $0.4304 \mathrm{Mgal} / \mathrm{d}$ for well $430 \mathrm{~A}$.

\section{Well 410}

The contributing area, differentiated by travel-time ranges, for well 410 is shown in figure 8. The contributing area for well 410 includes an area of the water table in the vicinity of the well and scattered portions of the water table along the valley wall and between the valley wall and the lake. Also shown as part of the contributing area to well 410 is a portion of Picatinny Lake. The travel time from the contributing area to well 410 is generally less than 10 years; the exceptions are most of the contributing area within Picatinny Lake and the farthest upvalley extent of the contributing area along the valley wall, where travel times are 10 years or greater, and generally are greater than 40 years.

Buildings 404, 407, and 454 are above the contributing area to well 410 . Benioff and others (1991) reported that hazardous materials, such as VOC's, trace elements, and propellants, were used in these buildings and may have contaminated the surrounding soils. The travel times from the contributing area to well 410 indicate that a contaminant that migrated from the vicinity of buildings 404,407 , and 454 downward to the water table could be transported to well 410 in less than 10 years.

TCE has been found in the unsaturated zone above, and in ground water within, the unconfined aquifer near that part of the contributing area near buildings 404 and 407 (Robert Rosman, written commun., 1991). The unconfined aquifer is represented by permeable layer A3 in this area of the model. Ground-water flow to well 410 from this part of the contributing area could allow the TCE-contaminated ground water to flow from the unconfined aquifer to well 410 , screened in the confined glacial aquifer (represented by permeable layer A5), in less than 10 years; indeed, low concentrations of TCE have been detected intermittently since 1981 in water from well 410 (Foster Wheeler USA, 1990; Sargent and others, 1986).

\section{Well 430A}

The contributing area for well 430A, differentiated by travel-time ranges, is shown in figure 9. The contributing area is upvalley from the well, and generally lies between the valley wall and Picatinny Lake, except for that part of the area that is within the lake. Flowpaths to well $430 \mathrm{~A}$ that originate in the Picatinny Lake part of the contributing area have a maximum travel time of 60 years. Travel times of ground water along the flowpaths that originate in the part of the contributing area beneath Picatinny Valley, to well $430 \mathrm{~A}$, are generally less than 10 years.

A fuel-oil spill from a broken underground pipe that connected an underground storage tank to the arsenal's powerhouse (building 506) was discovered in 1989 (Carpenter Environmental Associates, Inc., 1991). The spill is located near building 506 and within the contributing 


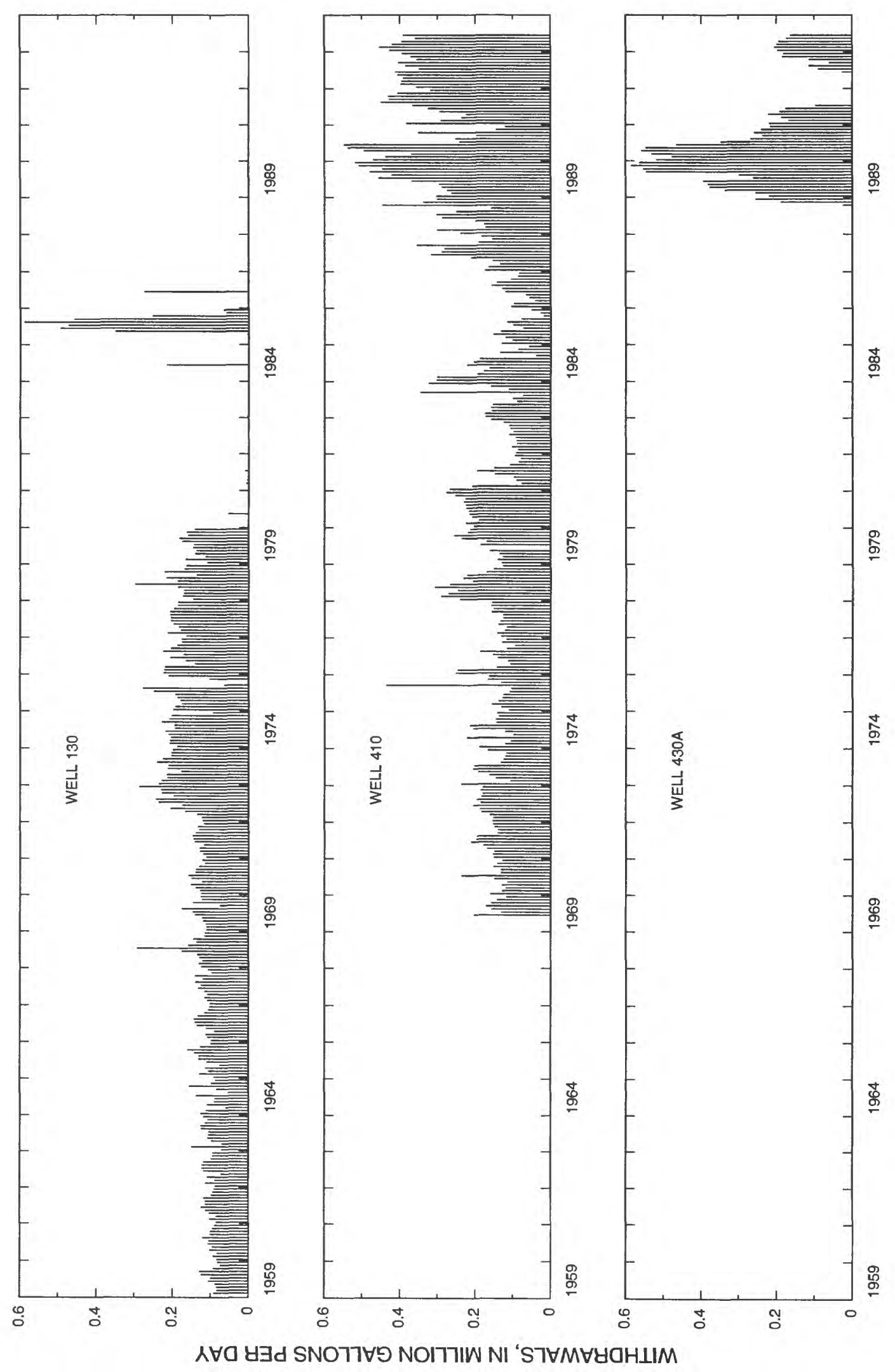

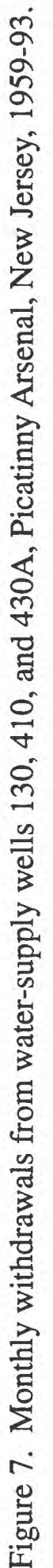




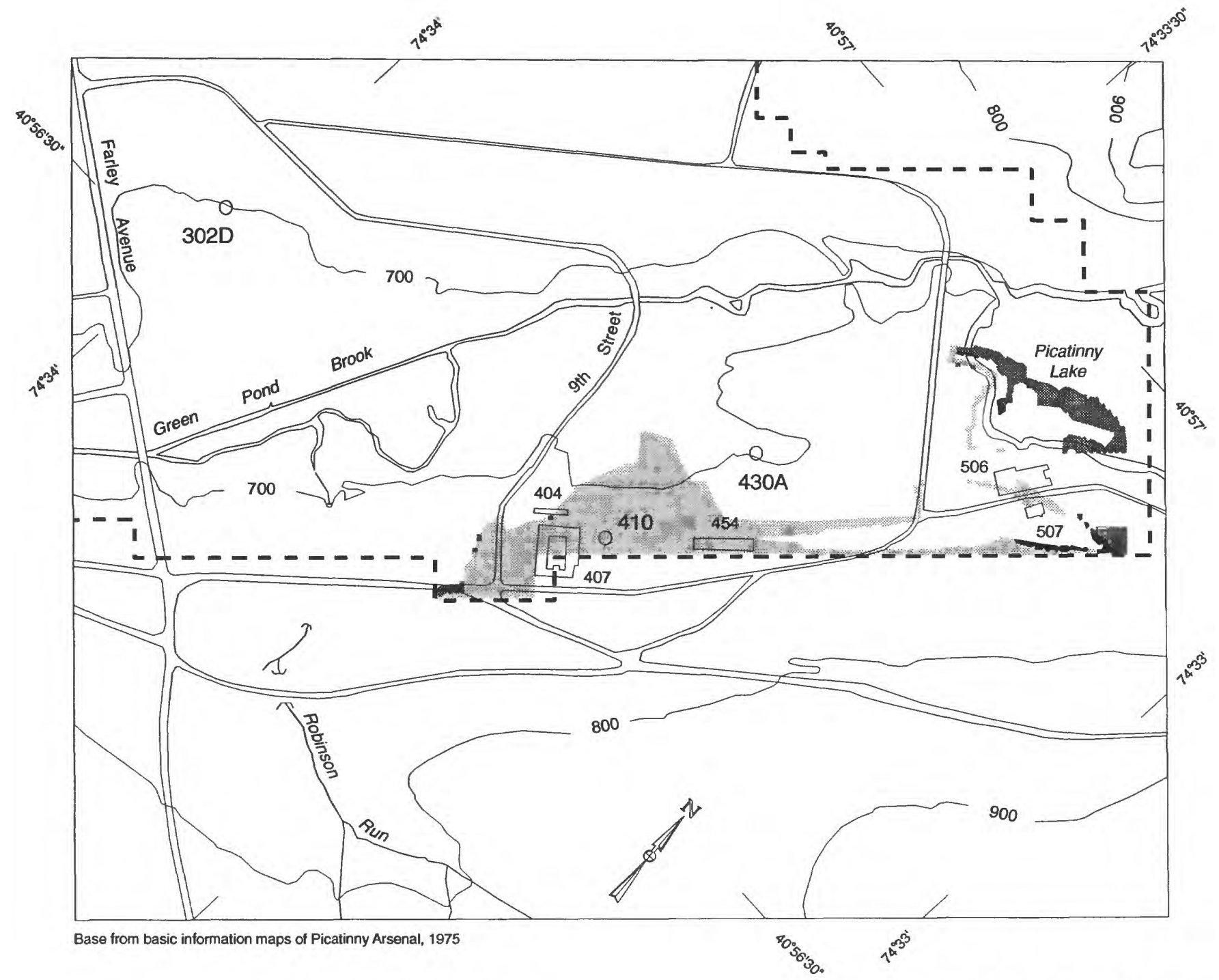

EXPLANATION

$\stackrel{404}{\leftrightharpoons}$ BUILDING WITH BUILDING NUMBER

CONTRIBUTING AREA TO WELL 410--Ground-water travel time from the contributing area to the well is less than or equal to 10 years

CONTRIBUTING AREA TO WELL 410--Ground-water travel time from the contributing area to the well is greater than 10 years but less than 40 years

-1. CONTRIBUTING AREA TO WELL 410--Ground-water travel time from the contributing area to the well is greater than or equal to 40 years

- - - - MODELED BOUNDARY BETWEEN WATER TABLE AND VALLEY WALL

- 800 - TOPOGRAPHIC CONTOUR--Shows line of equal land-surface elevation. Interval 100 feet. Datum is sea level

430A O WATER-SUPPLY WELL AND WELL NUMBER

Note: Broken drainage lines at Robinson Run indicate flow through underground culverts

Figure 8. Contributing area to water-supply well 410 at Picatinny Arsenal, New Jersey, showing ranges of ground-water travel time from the contributing area to the well (Simulated pumpage: well 410, 315 gallons per minute; well 430A, 160 gallons per minute; well 302D, 300 gallons per minute). 


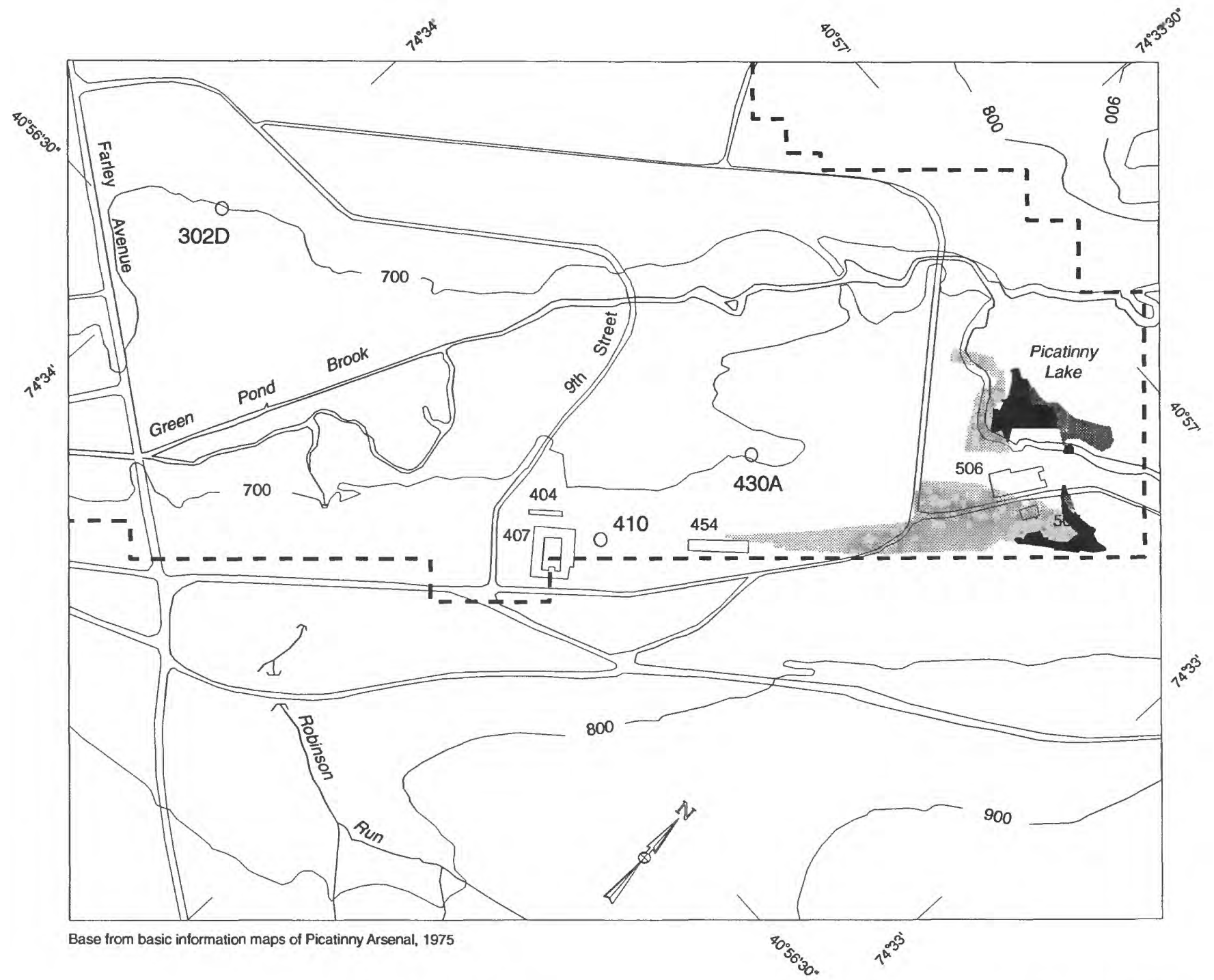

\section{EXPLANATION}

404 BUILDING WITH BUILDING NUMBER

CONTRIBUTING AREA TO WELL 430A--Ground-water travel time from the

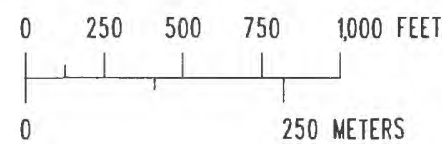

contributing area to the well is less than or equal to 10 years

CONTRIBUTING AREA TO WELL 430A--Ground-water travel time from the contributing area to the well is greater than 10 years but less than 40 years

2. CONTRIBUTING AREA TO WELL 430--Ground-water travel time from the contributing area to the well is greater than or equal to 40 years

\section{- - - - MODELED BOUNDARY BETWEEN WATER TABLE AND VALLEY WALL}

- 800 TOPOGRAPHIC CONTOUR--Shows line of equal larid-surface elevation. Interval 100 feet. Datum is sea level

430A O WATER-SUPPLY WELL AND WELL NUMBER

Note: Broken drainage lines at Robinson Run indicate flow through underground culverts

Figure 9. Contributing area to water-supply well 430A at Picatinny Arsenal, New Jersey, showing ranges of ground-water travel time from the contributing area to the well (Simulated pumpage: well 410, 315 gallons per minute; well 430A, 160 gallons per minute; well 302D, 300 gallons per minute). 
area to well 430A where ground-water travel times along flowpaths to the well are less than or equal to 10 years. Potential surficial sources of contaminants above the contributing area to well $430 \mathrm{~A}$ are hazardous materials, such as waste oils, solvents, and polychlorinated biphenyls (PCB's), from building 507 and building 511 (now destroyed) (Benioff and others, 1991). Contaminants from these surficial sources that migrated downward to the contributing area also would enter the ground-water-flow system in an area where travel times of ground water along flowpaths to well 430A are 10 years or less. Despite the potential for contamination and the presence of contaminants within the contributing area, results of water-quality analyses of samples from well 430A collected during 1981-90 showed no significant concentrations of contaminants; only 1,1,1-trichloroethane occasionally was detected, in low concentrations $(<3$ micrograms per liter) (Sargent and others, 1986).

The predicted contributing areas to wells 410 and $430 \mathrm{~A}$ are complementary. The simulated simultaneous pumping of these wells, their proximity to each other, and the continuity and hydrologic consistency of the permeable layers and confining units of the aquifer system around the wells result in an interdependent, combined contributing area. Figure 10 shows the two polygons that form the combined contributing area for these wells; one is near the valley wall and the other is below Picatinny Lake.

\section{Wells 130 and 302D}

The contributing areas to wells 130 and 302D are shown in figures 11 and 12 , respectively. The contributing areas overlap because pumpage from these wells was simulated in two model scenarios--one with only well 130 being pumped and the other with wells $302 \mathrm{D}, 410$, and $430 \mathrm{~A}$ being pumped. The contributing areas for each well are similar; they encompass an area of the water table between (and including) Bear Swamp Brook and the valley wall, and part of Picatinny Lake. The discontinuity of the two contributing areas, as well as the distribution of travel times within the contributing areas, may be a consequence of the complex and discontinuous stratigraphy of the aquifers and confining units around the wells. Predicted ground-water travel times from the contributing areas to the wells vary widely; flowpaths that originate nearest the wells are associated with the shortest travel time (less than or equal to 10 years). The longest travel times are associated with flowpaths that originate beneath Picatinny Lake; flowpaths that start here extend down to the bedrock aquifer (layer A6), then over to well 302D, or over and then up to well 130 (layer A5). Travel times to wells 130 and 302D along these flowpaths exceed 400 years.

The prediction of the contributing area to well 302D, the travel time from the contributing area to the well, and the existence of flowpaths that originate below Picatinny Lake and travel to well 130 are subject to limitations related to the simulation of the permeability characteristics of the carbonate-rock aquifer (A6). The heterogeneity of, orientation of, and vertical connection between secondary permeability features in this rock are poorly understood. Well 302D is open to $293 \mathrm{ft}$ of the carbonate rock, and may intercept flow from contributing areas other than those determined from simulation results. Flowpaths through layer A6 and their associated travel times also may differ from those predicted from simulation results.

The contributing areas to wells 130 and 302D include an area around building 24 where both documented and potential sources of contamination to ground water are found (Benioff and others, 1991). Because a plume of TCE-contaminated ground water that extends eastward from 


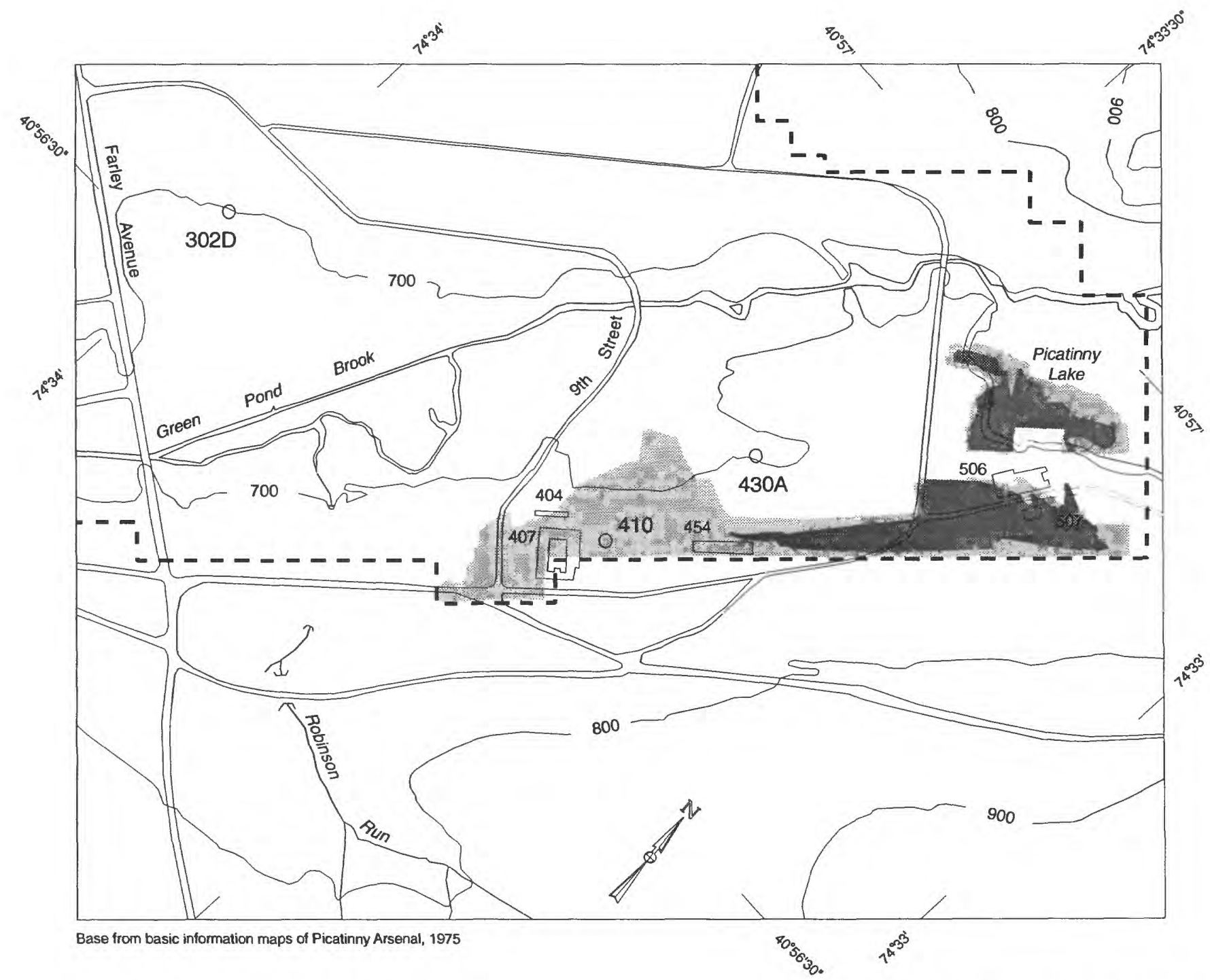

EXPLANATION

404 BUILDING WITH BUILDING NUMBER

2. CONTRIBUTING AREA TO WELL 410

CONTRIBUTING AREA TO WELL 430A $\begin{array}{ll}- & \text { MODELED BOUNDARY BETWEEN WATER TABLE } \\ \text { AND VALLEY WALL }\end{array}$

- 800 TOPOGRAPHIC CONTOUR--Shows line of equal land-surface elevation. Interval 100 feet. Datum is sea level

430A $\bigcirc$ WATER-SUPPLY WELL AND WELL NUMBER

Note: Broken drainage lines at Robinson Run indicate flow through underground culverts

Figure 10. Contributing area to water-supply wells $410 \mathrm{~A}$ and $430 \mathrm{~A}$ at Picatinny Arsenal, New Jersey, combined. 


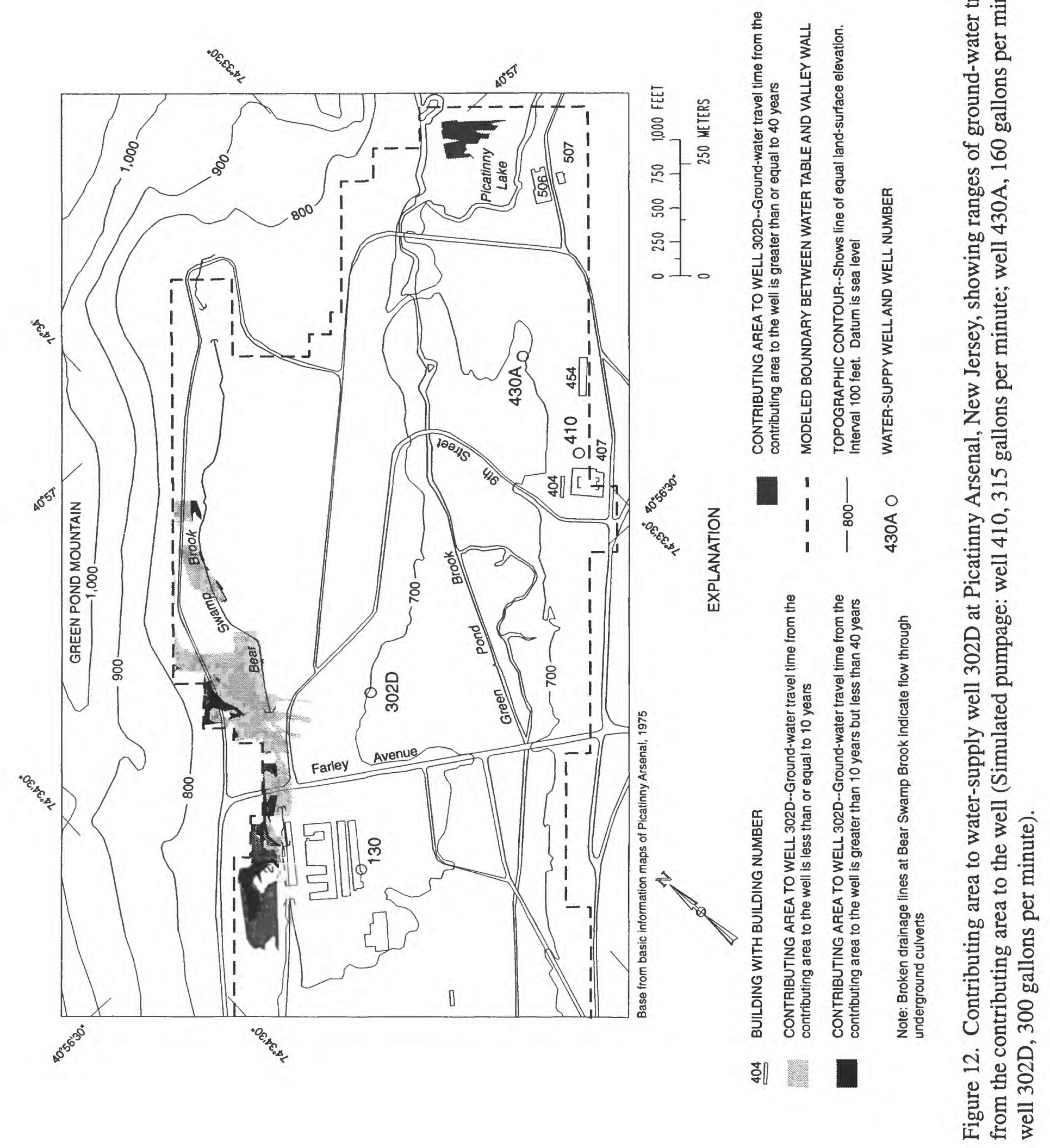


building 24 (Sargent and others, 1990) is within $100 \mathrm{ft}$ of the contributing areas to each well, a flowpath analysis was conducted to determine whether the plume could contribute any of the ground-water flow to either well when either well was being pumped. The flowpath analysis was done by placing 125 particles within each model cell in layers A1, A2, and A3 that corresponds to the three-dimensional location of the TCE contaminant plume determined by Imbrigiotta and Martin (1991, p. 676). The particles were forward-tracked and the starting locations and travel times of any particles that discharged to well 130 or $302 \mathrm{D}$ were recorded.

Results of the particle-tracking flowpath analysis indicate that no ground water from the TCE plume would flow to well 302D under simulated pumping conditions. No pumping history or water-quality information is available to evaluate the accuracy of this prediction.

Results of the particle-tracking analysis of ground-water flow from the TCE plume to well 130 are consistent with the water-quality data available for the well. Ground water from a part of the plume was predicted to flow to well 130 under simulated pumping conditions. The TCE plume extends downward into permeable layers $\mathrm{A} 1, \mathrm{~A} 2$, and $\mathrm{A} 3$; figure 13 shows the part of each layer that was predicted to contribute ground water to well 130 at the simulated pumping rate of $0.36 \mathrm{Mgal} / \mathrm{d}$. Well 130 was pumped regularly from 1959 to 1979 and then intermittently to 1985 , when pumping was terminated after results of repeated water-quality analyses showed the presence of TCE in the well (Sargent and others, 1986), indicating that ground water from the plume probably had migrated to the well. Travel times for ground water moving along flowpaths from the plume to well 130 generally are 10 years or less, and TCE contamination of ground water from the building 24 area may date to 1961 (Sargent and others, 1990).

\section{Limitations of Analysis and Evaluation of Results}

The inherent assumptions and limitations of the Picatinny valley-wide ground-water-flow model must be considered in evaluating the results of the particle-tracking analysis of groundwater flowpaths used to determine contributing areas and ground-water travel times to watersupply wells at Picatinny Arsenal. First, a model is only an approximation of the physical system. Local-scale heterogeneities not represented in the model and discretization of the aquifer system affect the results. Second, although the model was used to simulate steady-state conditions, the natural hydrologic condition is a dynamic equilibrium that includes fluctuations in flowpaths that result from natural and human-induced hydrologic changes (Buxton and Modica, 1992). Average, not dynamic, conditions of recharge and pumping were simulated with the steady-state model. Third, the simulation results presented herein are based on the current, and as yet incomplete, understanding of the ground-water-flow system at Picatinny Arsenal. The model representation of the actual system will be improved as additional data are collected. Fourth, the model was used to simulate flow to a well. Prediction of potential travel times of ground-water contaminants to wells are made on the basis of simulation results without considering the processes that affect and limit contaminant transport in natural systems. Contaminant transport is assumed to be conservative with no attenuation by dispersive, geochemical, or biological processes; therefore, predicted contaminant travel times can be considered to represent the minimum time required for ground water containing a dissolved contaminant to flow from a contributing area to a well. 


\section{EXPLANATION}

24 BUILDING WITH BUILDING NUMBER

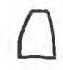

AREAL EXTENT OF PLUME OF TRICHLOROETHYLENE-CONTAMINATED GROUND WATER ORIGINATING AT BUILDING 24

AREA OF PLUME OF TRICHLOROETHYLENE-CONTAMINATED GROUND WATER PREDICTED TO CONTRIBUTE GROUND WATER TO WELL 130--Ground-water travel time from the plume to the well is less than or equal to 10 years

AREA OF PLUME OF

TRICHLOROETHYLENE-CONTAMINATED GROUND WATER PREDICTED TO CONTRIBUTE GROUND WATER TO WELL 130--Ground-water travel time from the plume to the well is greater than 10 years but less than 40 years

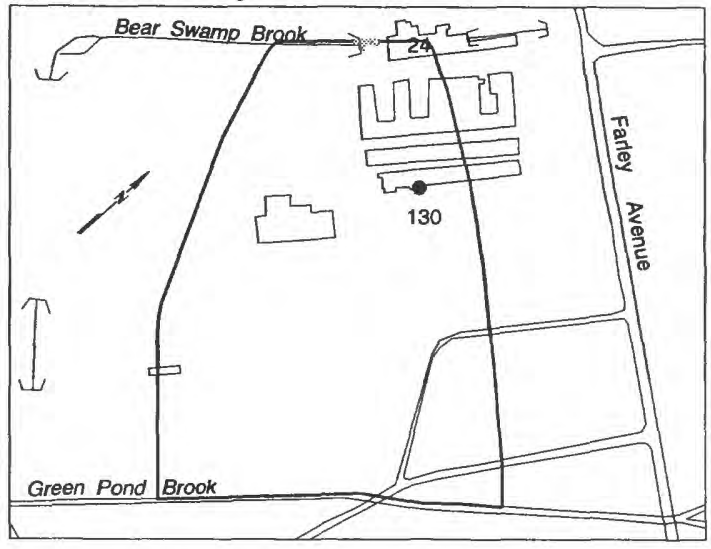

(b) Permeable layer A2

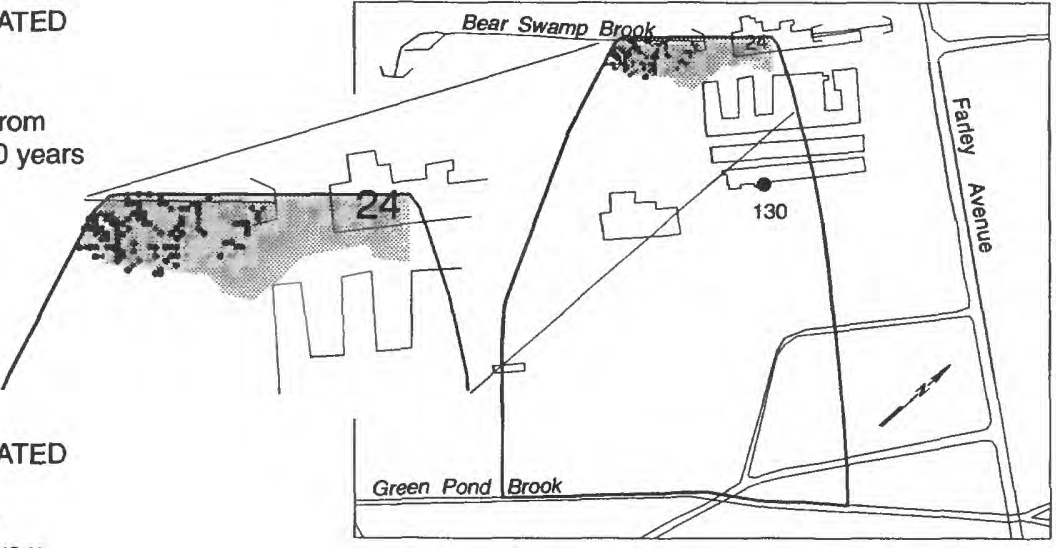

AREA OF PLUME OF

TRICHLOROETHYLENE-CONTAMINATED

GROUND WATER PREDICTED TO

CONTRIBUTE GROUND WATER TO

WELL 130--Ground-water travel time from

the plume to the well is greater than or equal

to 40 years

WATER-SUPPLY WELL AND WELL NUMBER

(c) Permeable layer A3

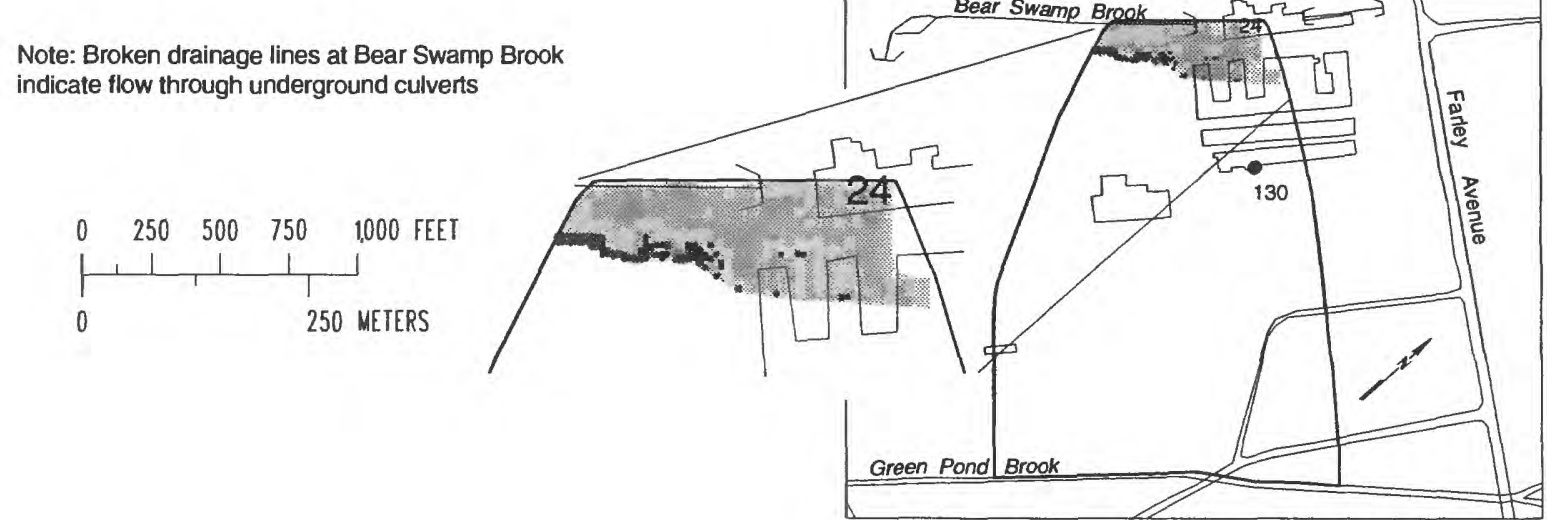

Base from basic information maps of Picatinny Arsenal, 1975

Figure 13. Areas of plume of trichloroethylene-contaminated ground water originating at building 24 at Picatinny Arsenal, New Jersey, predicted to contribute ground water to well 130 from permeable layer (a) A1, (b) A2, and (c) A3 (Simulated pumpage: well 130, 250 gallons per minute). 
The product of a particle-tracking analysis is a quantitative representation of simulation results. However, simulation results contain inherent errors introduced as a consequence of inconsistencies between the model and the actual system. Therefore, particle-tracking results were compared qualitatively so that the simulated pumping alternatives could be evaluated effectively while minimizing these errors.

Results of flowpath analysis for wells 130 and 302D indicate that well 302D would produce water of better quality than well 130 . The travel times predicted for ground water to move to well 302D along flowpaths that originate in its contributing area in the vicinity of building 24 generally are greater than 10 years, whereas the travel times predicted for ground water to move to well 130 along flowpaths that originate in that part of its contributing area that is in the vicinity of building 24 generally are 10 years or less. Longer travel times for ground water flowing from the building 24 area to well 302D would increase the likelihood of geochemical attenuation and biological degradation of any contaminants that might be in the water. In addition, ground water is predicted to flow from the TCE plume to well 130 (travel time generally 10 years or less) but not to well 302D, which also qualitatively indicates that the quality of water pumped from well 302D is likely to be better than that of water pumped from well 130 .

\section{SUMMARY AND CONCLUSIONS}

Ground-water flow to Picatinny Arsenal's water-supply wells 130, 302D, 410, and 430A was simulated with a previously developed valley-wide finite-difference flow model. The Picatinny Valley ground-water-flow system is composed of a sequence of five glacial aquifers overlying a carbonate-bedrock aquifer. The model was refined to include springs at the base of the southeastern valley wall from which water has been observed to discharge, flow a short distance on the surface, and then infiltrate to the subsurface. The spring discharge was input to the model as point recharge where the water infiltrates to the subsurface. The model was calibrated to average annual recharge and nonpumping (steady-state unstressed) conditions by using streamdischarge data from Green Pond Brook and ground-water levels measured during nonpumping conditions in January 1993.

The calibrated model was used to simulate steady-state ground-water flow for two alternatives--one with wells $410,430 \mathrm{~A}$, and 302D being pumped and the other with well 130 being pumped. A particle-tracking flowpath analysis of simulation results was conducted to define the contributing areas to the pumped water-supply wells and to quantify the travel times along the flowpaths from a well's contributing area to the well. Results of the flowpath analysis were used to evaluate the potential for ground water to flow from the TCE plume near building 24 to either well 130 or well 302D.

Results of the flowpath analysis for well 410 indicated the presence of several potential sources of ground-water contamination in the unsaturated zone above the contributing area. Further, they showed that TCE-contaminated ground water known to be present in the unconfined aquifer beneath the contributing area to well 410 could reach the well in 10 years or less. 
The flowpath analysis for well 430A showed the presence of two potential sources of ground-water contamination in the unsaturated zone above the contributing area. Fuel oil spilled from an underground storage tank adjacent to building 506 also is present above the contributing area to well 430A. Predicted travel time from the parts of the contributing area that are near these sources to well $430 \mathrm{~A}$ is 10 years or less.

The contributing areas to wells 130 and 302D include areas of the water table that are near documented and potential ground-water-contamination sources in the vicinity of building 24 . Travel time from this area generally is longer (greater than 10 years) for water flowing to well 302D than for water flowing to well 130 (10 years or less). Under simulated pumping conditions, water from the TCE plume near building 24 is predicted to reach well 130 but not well 302D. 


\section{REFERENCES CITED}

Benioff, P.A., Bhattacharyya, M.H., Biang, C., Chiu, S.Y., Miller, S., Patton, T., Pearl, R., Yonk, A., and Yuen, C.R., 1991, Remedial investigation concept plan for Picatinny Arsenal, volume 2: Descriptions of and sampling plans for remedial investigation sites: Argonne, Ill., Environmental Assessment and Information Sciences Division, Argonne National Laboratory, 18 chap.

Buxton, H. T., and Modica, Edward, 1992, Patterns and rates of ground-water flow on Long Island, New York: Ground Water, v. 30, p. 857-866.

Carpenter Environmental Associates, Inc., 1991, Picatinny Arsenal discharge investigation and corrective action report: Ramsey, New Jersey, unpublished consultant's report.

Foster Wheeler USA, 1990, Report on facilities and building: Previous and current operations at specific buildings, Picatinny Arsenal: unpublished consultant's report.

Imbrigiotta, T.E., and Martin, Mary, 1991, Overview of research activities on the movement and fate of chlorinated solvents in ground water at Picatinny Arsenal, New Jersey, in

U. S. Geological Survey Toxic Substances Hydrology Program--Proceedings of the technical meeting, Monterey, California, March 11-15, p. 673-680.

McDonald, M.G., and Harbaugh, A.W., 1983, A modular three-dimensional finite-difference ground-water flow model: U.S. Geological Survey Techniques of Water-Resources Investigations, book 6, chap. A1, 528 p.

Pollock, D.W., 1989, Documentation of computer programs to compute and display pathlines using results from the U.S. Geological Survey modular three-dimensional finite- difference ground-water flow model: U.S. Geological Survey Open-File Report 89-381, 188 p.

Sargent, B. P., Green, J. W., Harte, P. T., and Vowinkel, E. F., 1986, Ground-water quality data for Picatinny Arsenal, New Jersey, 1958-85: U.S. Geological Survey Open-File Report 86-58, $66 \mathrm{p}$.

Sargent, B. P., Fusillo T. V., Storck, D. A., and Smith, J. A., 1990, Assessment of contamination of ground water and surface water in the area of Building 24, Picatinny Arsenal, New Jersey, 1986-87: U.S. Geological Survey Water-Resources Investigations Report 90-4057, 120 p.

Voronin, L. M., 1991, Simulation of ground-water flow at Picatinny Arsenal, New Jersey, in Mallard, G.E., and Aronson, D. A., eds., U.S. Geological Survey Toxic Substances Hydrology Program--Proceedings of the technical meeting, Monterey, California, March 11-15, p. 713-720.

Wolfe, P. E., 1977, The geology and landscapes of New Jersey: New York, Crane, Russak \& Company, $351 \mathrm{p}$. 